\title{
Geochemical study on hot-spring water in West New Britain Province, Papua New Guinea
}

\author{
M. M. Lahan, R. T. Verave, and P. Y. Irarue \\ Geological Survey Division, Mineral Resources Authority, P.O. Box 1906, Port Moresby, \\ NCD, Papua New Guinea \\ Correspondence to: M. M. Lahan (mlahan@mra.gov.pg)
}

Received: 10 June 2015 - Revised: 7 September 2015 - Accepted: 7 September 2015 - Published: 13 October 2015

\begin{abstract}
West New Britain Province, which occupies the western part of New Britain Island in Papua New Guinea, is ideally located within an active tectonic region that influences volcanism creating an environment favourable for geothermal activity. Geothermal mapping of surface manifestations reveals high temperature geothermal prospects along the northern coastline of West New Britain Province that are further confirmed by geochemical analysis. The occurrence of geothermal features is confined to the Quaternary Kimbe Volcanics and alluvium in the lowland areas. The features in Talasea appear to be controlled by deep-seated northerly trending faults while structures in Hoskins also appear to be deep seated but have not been identified. The geothermal systems in West New Britain Province have not been drilled, but preliminary reconnaissance geothermal mapping and geochemical analysis reveals four high temperature geothermal prospects suitable for further investigation and development of geothermal energy. These are the Pangalu (Rabili) and Talasea Station geothermal prospects in Talasea and Kasiloli (Magouru) and Silanga (Bakama and Sakalu) geothermal prospects in Hoskins. The calculated reservoir temperatures for these fields are in the range of $245-310^{\circ} \mathrm{C}$. Recommendations are made for further follow-up exploratory investigations.
\end{abstract}

\section{Introduction}

The volcanic island of New Britain is the most prospective region for the development of geothermal energy resources in Papua New Guinea (PNG). The island is located east of mainland PNG and lies between the Manus Basin to the north and the New Guinea Trench to the southeast (Fig. 1). The geothermal prospects are scattered on the northern coastline from the Willaumez Peninsula in Talasea, West New Britain Province (WNBP), to the Gazelle Peninsula in Rabaul, East New Britain Province (ENBP) (Fig. 1). Volcanically, New Britain Island is comprised of several dormant volcanoes and two currently active volcanoes: Pago in Cape Hoskins area in WNBP and the Rabaul (Tavurvur) volcano in the Gazelle Peninsula in ENBP. WNBP occupies the western and most of the central part of New Britain Island while the eastern portion is occupied by ENBP.

West New Britain Province hosts a large oil palm industry that serves as its main economic activity apart from other business activities in Kimbe (its provincial capital) and its smaller towns, Hoskins and Bialla. There are approximately 128800 people (NRI Report, 2010) in the Talasea District of WNBP who directly or indirectly depend on oil palm for their livelihood. The main sources of electricity for the province is by the use of four $400-600 \mathrm{~kW}$ diesel generators and two mini-hydro power plants supplied by PNG Power Limited (J. Aska, Kimbe generation team leader, personal communication, 2013). The oil palm plantations in the province provide some of their own energy due to insufficient electricity needs and frequent power outages.

Geoscientific information on the geothermal prospects in the country including WNBP is sparse although previous reconnaissance geochemical survey undertaken in Talasea provided temperatures which ranged from 44 to $101^{\circ} \mathrm{C}$ (Berhane and Mosusu, 1997). There has never been any geophysical survey for geothermal exploration, nor has there been drilling conducted in the country except on Lihir Island, where a $56 \mathrm{MW}$ geothermal power plant is in operation supporting the gold mine. PNG through Mineral Resources Au- 


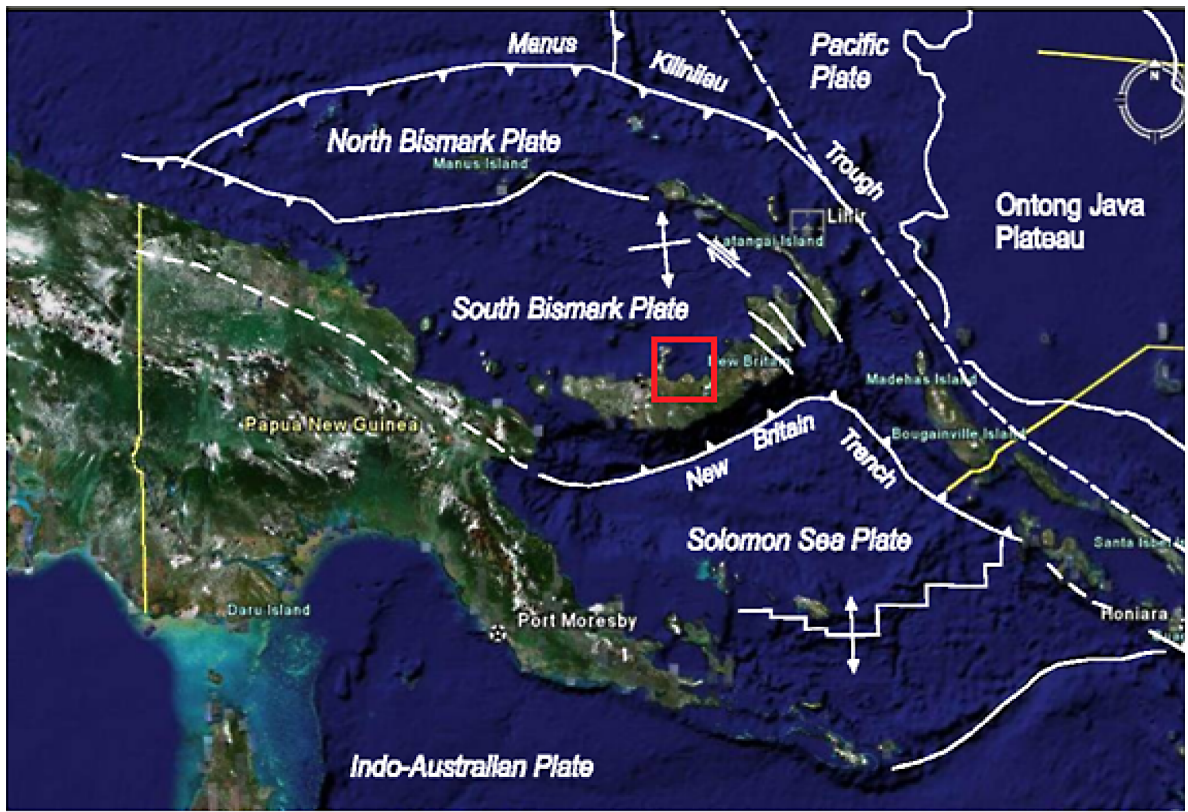

Figure 1. Map of PNG showing the tectonic setting and study area (red square) on New Britain Island. Modified from Williamson and Hancock, 2005.

thority (MRA) has now embarked on undertaking geothermal exploration in the country with assistance from the World Bank and the Government of Iceland through training of its staff, as there is a need to diversify its energy source and increase the energy needs of the country.

The reconnaissance field survey of the various geothermal sites in the Talasea District of WNBP was undertaken in November 2012 as part of MRA's ongoing geothermal exploration work. This report provides the results of the geochemical analysis of the water samples and attempts at identifying prospective geothermal sites for further exploratory work.

\section{Geological setting and geothermal features}

\subsection{Tectonic setting}

New Britain Island is part of the New Guinea island arc complex that represents the tectonically active margin of the Australian continental mass. It is situated in a collision zone between three major plates: the northward-moving Indo-Australian, the west-northwest-moving Pacific and the eastward-moving Caroline plates. The boundary between the Pacific and the Australian plates is marked by a number of microplates: the Solomon Plate in the southeast and North and South Bismarck plates to the north of the island (Johnson and Molnar, 1972). These microplates located offshore are bounded by spreading ridges, deep-sea trenches and transform faults while those onshore are represented by thrusts, extensional and strike-slip faults and folds. Earthquakes are located on these spreading ridges (Davies, 2009).
The PNG region experiences very high seismicity due to its location on the "Ring of Fire". The main concentration of seismicity is at the northern and northeastern margins of the Solomon Sea where the Solomon Plate is subducted northward beneath the South Bismarck and the Pacific plates along the New Britain Trench (Fig. 2). Seismicity in this area has been described as the most intense in the world (Ripper and McCue, 1983; Cooper and Taylor, 1989). Seismicity continues from this area towards the southeast through the Solomon Islands, and towards the northwest under the northern part of the New Guinea Island. The volcanoes of New Britain are the result of subduction of the northward-migrating Solomon Sea plate under the South Bismarck Plate. The volcanoes in the Solomon Islands are associated with the Solomon Sea plate as it is subducted beneath the Pacific Plate.

\subsection{Geology}

New Britain Island is mostly comprised of Tertiary to Quaternary volcanic materials. Several dormant and active volcanoes exist along the northern coastline from west to east (Lowder and Carmichael, 1970). Baining Volcanics (Teb) which accumulated in an Eocene island arc are the oldest rock type on the island. It is comprised of massive to well-bedded indurated and strongly jointed volcanic breccia, conglomerate, sandstone and siltstone, basic to intermediate lavas and hypabyssal rocks, tuff and minor limestone. There is widespread occurrence of andesitic to basaltic intrusives on the island. In the West New Britain area, deposition of Kapuluk Volcanics (Tok) occurred when volcanism resumed in the late Oligocene. The Kapuluk Volcanics are of simi- 


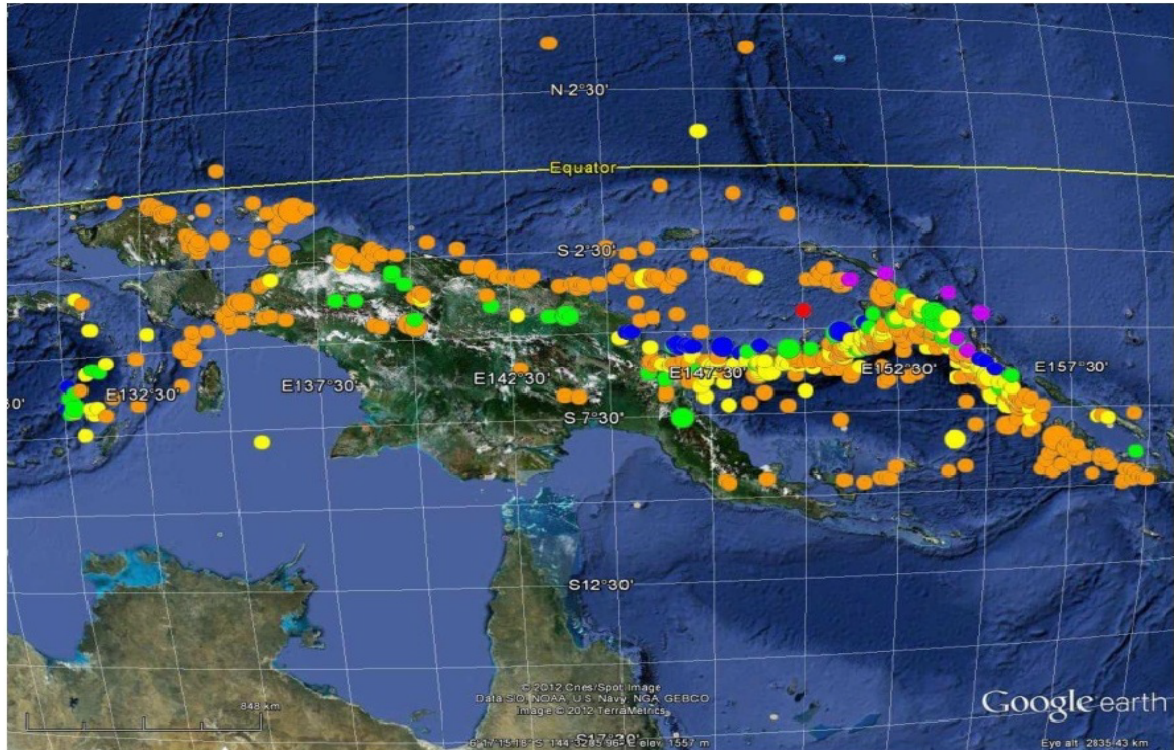

Figure 2. Earthquakes of magnitude 6 or greater in the PNG region between 1972 and 2012. Depths: orange - 0-35 km, yellow - 35$70 \mathrm{~km}$, green $-70-150 \mathrm{~km}$, blue $-150-300 \mathrm{~km}$, pink $-300-500 \mathrm{~km}$, and red $-500-800 \mathrm{~km}$. From the USGS/NEI database, accessed at http://earthquakes.usgs.gov/earthquakes/eqarchives/epic.rect.php (after Sheppard and Cranfield, 2012).

lar lithology to the Baining Volcanics but markedly less indurated, jointed and fractured and widely zeolitized. Slow regional subsidence during a period of volcanic quietness in the early Miocene to early Pliocene allowed large thicknesses of the Yalam Limestone (Tmy) to accumulate in reefs and interreef basins with little or no contaminations from terrestrial sources. It consists of compact or porous, massive to wellbedded bioclastic limestone, chalk, calcareous siltstone and mudstone with minor calcirudite (Ryburn, 1975).

Renewed volcanism in Pliocene formed the Mungu Volcanics (Tpm) found southeast of Stettin Bay, which is comprised of dacite, rhyodacite, andesite and pumiceous tuff. They possibly represent the volcanoes that supplied the tuffaceous material in the Kapiura Beds (Tpk) found east of Kasiloli thermal area. The Kapiura Beds consist of semiconsolidated, massive to well-bedded acid tuffaceous sandstone, siltstone and conglomerate, tuff, calcareous sediments and limestone. The Talasea Peninsula and Mt Pago area near Hoskins are comprised of Quaternary Kimbe Volcanics, which are basaltic to rhyolitic pyroclastics and lavas as well as hypabyssal intrusives, while the Silanga geothermal area is found in Quaternary alluvium of gravel, sand and silt (Ryburn, 1975). Field observations during this survey noted that the Kimbe Volcanics at geothermal sites are strongly altered to clay due to thermal activity. Structures are difficult to identify; however, observations of the geothermal occurrences show existence of northerly trending faults in the Talasea Peninsula, which is a similar trend to faults mapped by Ryburn (1975). The geology of the survey area by Ryburn (1975) is presented in Fig. 3.

\subsection{Geothermal prospects and samples}

There are at least seven geothermal prospects in WNBP (Grindley and Nairn, 1974) as shown in Fig. 4: PangaluTalasea, Bola, Garbuna, Kasiloli-Hoskins, Walo (Silanga), Galloseulo and Bamus. Five of the seven prospects were investigated during this field work: Pangalu-Talasea, Bola and Garbuna (Garu area west of Garbuna) in the Willaumez (Talasea) Peninsula and Silanga and Kasiloli prospects in the Hoskins area. Galloseulo and Bamus prospects located in the east were not visited. In this report, Pangalu and Talasea are presented as separate prospects and Bola is part of Talasea.

A total of 36 geothermal surface features or manifestations (geysers, hot springs, mud pools/pots, fumaroles and/or steaming grounds) were mapped and field observations including basic measurements such as temperature, $\mathrm{pH}$, salinity, conductivity and feature dimension taken. Water and gas samples were collected from selected sites: 13 spring samples, 7 gas samples and a meteoric water sample from Lake Dakataua located at the northern tip of Willaumez Peninsula. Details of sample sites are listed in Table 1 and locations shown in Fig. 3. The samples were sent to the New Zealand Geothermal Analytical Laboratory (NZGAL), GNS Science, Wairakei, for analysis. All gas samples were reportedly contaminated with air and were not analysed. The contamination of the gas samples by air is likely due to samples collected from small gas seeps using improper equipment. The majority hot-spring samples and the meteoric water sample (10) are from Willaumez Peninsula, three from Silanga and one from Kasiloli geothermal prospects. These features are located within oil palm plantations, near settlements and within 


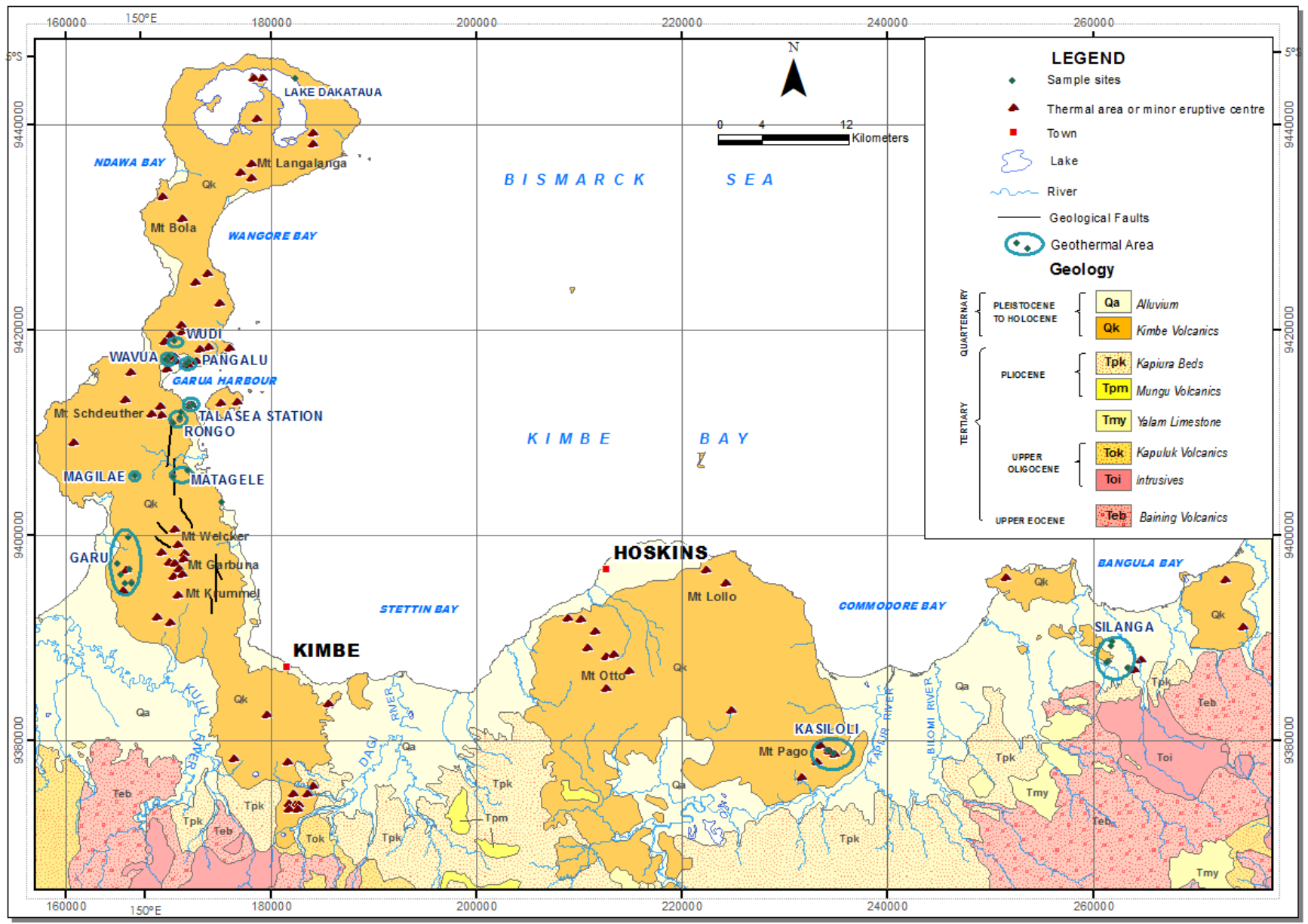

Figure 3. Geology of the Talasea-Hoskins area showing the locations of the geothermal sites visited (map after Ryburn, 1975).

close proximity to Kimbe and Hoskins towns, hence easily accessible.

\section{Fluid chemistry and geothermometry}

\subsection{Fluid chemistry}

The chemical compositions of the 14 water samples in terms of major and minor geothermal constituents are presented in Table 2. The local meteoric lake water (i.e. Lake Dakataua) and seawater (Pichler, 2005) are included in the table.

Using the $\mathrm{Cl}-\mathrm{SO}_{4}-\mathrm{HCO}_{3}$ plot in Fig. 5, different types of thermal waters are distinguished such as steam-heated and volcanic waters based on major anion concentrations $\left(\mathrm{Cl}, \mathrm{SO}_{4}\right.$ and $\left.\mathrm{HCO}_{3}\right)$. As shown in Fig. 5, the Rabili, Talasea Station, Bakama 1 and Magouru springs are classified as matured waters, Galu and Tabero as volcanic waters, Lake Dakataua and Rongo 1 as peripheral waters and the rest of the hot springs as steam heated waters. The matured geothermal waters appear to be clear neutral-chloride boiling springs with very high chloride content compared to the $\mathrm{SO}_{4}$ and $\mathrm{HCO}_{3}$ components. The chloride concentration of

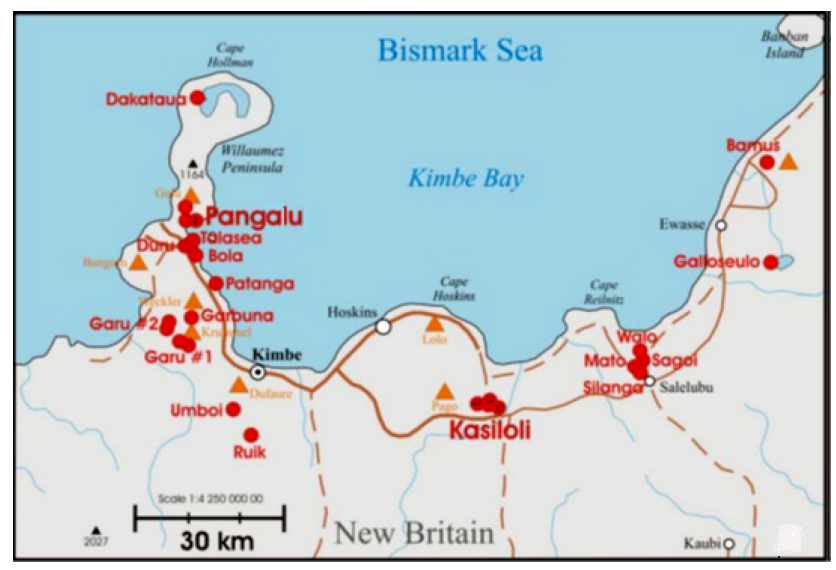

Figure 4. Map of central New Britain (see Fig. 2) between Willaumez Peninsula and Banban Island, showing the location of thermal areas (red circles) and active volcanoes (triangles). Map after Grindley and Nairn (1974) taken from McCoy-West et al. (2009). 
Table 1. List of geothermal features sampled for water and gas analysis and their localities.

\begin{tabular}{|c|c|c|c|c|}
\hline District & Area & Feature name & Water & Gas \\
\hline \multirow{10}{*}{ 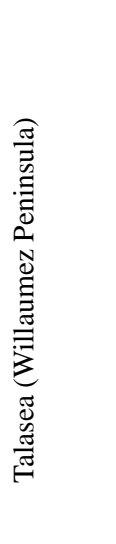 } & Pangalu & Rabili & 1 & 2 \\
\hline & Wavua & Wavua 1 & 1 & 1 \\
\hline & Wudi & Wudi & 1 & \\
\hline & \multirow{2}{*}{ Talasea Station } & Talasea Station & 1 & \\
\hline & & Rongo 1 & 1 & \\
\hline & \multirow{2}{*}{$\begin{array}{l}\text { N. Gabuna } \\
\text { N. Gabuna }\end{array}$} & Matagele & 1 & 1 \\
\hline & & Magilae & 1 & \\
\hline & \multirow{2}{*}{ W. Gabuna } & Garu & 1 & 1 \\
\hline & & Tabero & 1 & 1 \\
\hline & Lake Dakataua & Lake Dakataua & 1 & \\
\hline \multirow{4}{*}{ Hoskins } & Kasiloli & Magouru & 1 & 1 \\
\hline & \multirow{3}{*}{ Silanga } & Bakama 1 & 1 & \\
\hline & & Sakalu/Mato & 1 & \\
\hline & & Taliau & 1 & \\
\hline
\end{tabular}

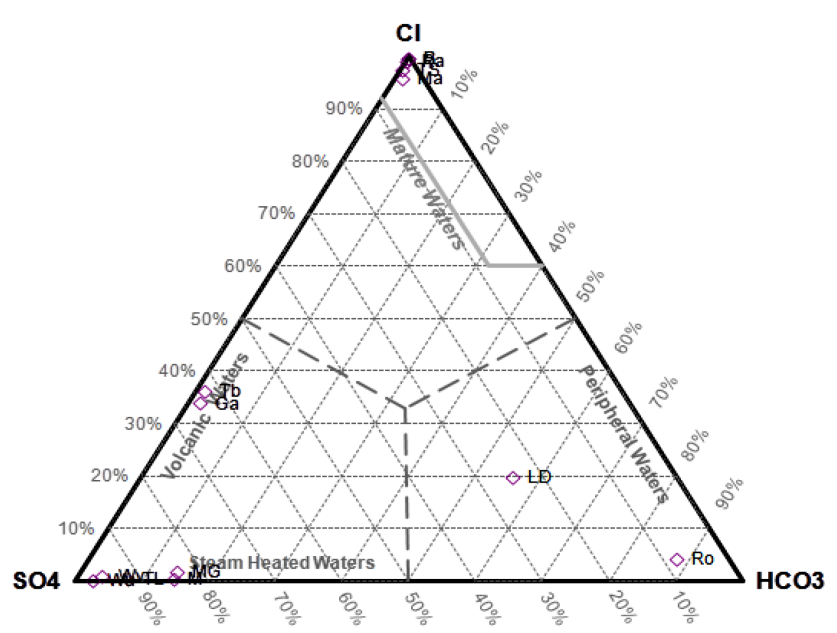

Figure 5. Ternary plot showing relative concentrations of the anions chloride $(\mathrm{Cl})$, sulfate $\left(\mathrm{SO}_{4}\right)$ and bicarbonate $\left(\mathrm{HCO}_{3}\right)$. Plot has been generated using a spreadsheet created by Powell and Cumming (2010). Ra - Rabili, Wv - Wavua 1, TS - Talasea Station, Ro - Rongo 1, M - Matagele, MG - Magilae, LD - Lake Dakataua, Wu - Wudi, Ga - Galu, Tb - Tabero, B - Bakama 1, TL - Taliau, S - Sakalu, Ma - Magouru.

Rabili hot spring ( $18993 \mathrm{mg} \mathrm{L}^{-1}$ ) is close to that of seawater $\left(19520 \mathrm{mg} \mathrm{L}^{-1}\right)$; hence there is likely infiltration of seawater due to its location along the shoreline. The volcanic waters discharge sulfuric gas and sulfur deposits as observed in the Garu area as is indicated by their $\mathrm{SO}_{4}$ content. The rest of the steam-heated waters have high $\mathrm{SO}_{4}$ and low $\mathrm{Cl}$ and

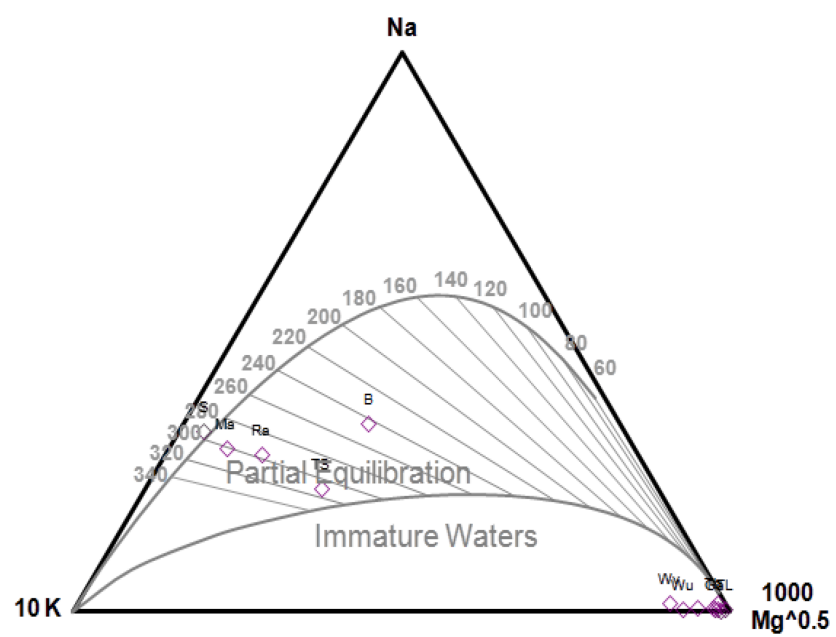

Figure 6. Ternary plot showing relative concentrations of $\mathrm{Na}, \mathrm{K}$ and $\mathrm{Mg}$ and the $\mathrm{Na}-\mathrm{K}$ and $\mathrm{K}-\mathrm{Mg}$ geothermometers (Giggenbach, 1988). Plot has been generated using a spreadsheet created by Powell and Cumming (2010). Ra - Rabili, Wv - Wavua 1, TS - Talasea Station, Ro - Rongo 1, M - Matagele, MG - Magilae, LD - Lake Dakataua, Wu - Wudi, Ga - Galu, Tb - Tabero, B - Bakama 1, TL - Taliau, S - Sakalu, Ma - Magouru.

are very acidic $(\mathrm{pH}=1-4)$. Their acidity is caused by steam heating of shallow groundwater and oxidation of $\mathrm{H}_{2} \mathrm{~S}$ to $\mathrm{SO}_{4}$ in which there is insignificant $\mathrm{Cl}$ discharged.

The Na-K-Mg plot in Fig. 6 further classifies the waters into fully equilibrated, partially equilibrated and immature waters based on the temperature dependence of the full equilibrium assemblage of potassium and sodium minerals that are expected to form after isochemical recrystallization of average crustal rock under conditions of geothermal interest (Giggenbach, 1988). It can be used to predict the equilibrium temperature and also the suitability of thermal waters for ionic geothermometers. As shown in Fig. 6, Sakalu is the only spring that has fully equilibrated with a calculated reservoir temperature of $295^{\circ} \mathrm{C}$ while Magouru, Rabili, Talasea Station and Bakama 1 have partially equilibrated with calculated reservoir temperatures of $300,295,310$ and $245^{\circ} \mathrm{C}$ respectively.

\subsection{Geothermometry}

The application of chemical geothermometry to fully and partially equilibrated waters directly estimates the reservoir fluid temperatures. This is based on the principle that specific temperature-dependent mineral-solution equilibria are attained in the geothermal reservoir. As some fluid in this equilibrated reservoir escapes and rises to a hot spring through buoyancy, it will usually cool by conduction and mix faster than it will chemically re-equilibrate. Some chemical species like silica equilibrate faster than others like sodium and potassium; therefore, the chemical composition of hot springs can be used to interpret the temperature and mixing 
Table 2. Hot-spring compositions in $\mathrm{mg} \mathrm{L}^{-1}$ except where noted.

\begin{tabular}{|c|c|c|c|c|c|c|c|c|c|c|c|c|c|c|c|c|c|c|c|c|}
\hline $\begin{array}{l}\text { Sample } \\
\text { name }\end{array}$ & Lab no. & Date & $\begin{array}{l}\text { Temp } \\
\left({ }^{\circ} \mathrm{C}\right)\end{array}$ & $\mathrm{pH}$ & $\mathrm{Na}$ & K & $\mathrm{Ca}$ & $\mathrm{Mg}$ & $\mathrm{SiO}_{2}$ & B & $\mathrm{Cl}$ & $\mathrm{SO}_{4}$ & $\mathrm{HCO}_{3}$ & $\mathrm{H}_{2} \mathrm{~S}$ & $\mathrm{NH}_{3}$ & As & $\mathrm{Fe}$ & $\mathrm{Al}$ & $\mathrm{Mn}$ & $\begin{array}{r}\text { Cond. } \\
\mu \mathrm{S} \mathrm{cm}^{-1}\end{array}$ \\
\hline $\begin{array}{l}\text { Feature-1 } \\
\text { RABILI }\end{array}$ & 2013000037 & $08 / 11 / 2012$ & 22 & 5.32 & 9697 & 1965 & 961 & 25 & 447 & 24 & 18993 & 153 & $<20$ & $<0.01$ & 7.1 & 1.9 & 0.55 & $<0.15$ & 2.7 & 46830 \\
\hline $\begin{array}{l}\text { Feature-5 } \\
\text { WAVUA } 1\end{array}$ & 2013000038 & $04 / 11 / 2012$ & 22 & 2.6 & 61 & 35 & 52 & 13.4 & 457 & 0.58 & 5.5 & 543 & $<20$ & 0.27 & 9.6 & 0.029 & 11.5 & 2.5 & 1.4 & 1956 \\
\hline $\begin{array}{l}\text { Feature-6 } \\
\text { TALASEA } \\
\text { STN }\end{array}$ & 2013000039 & $05 / 11 / 2012$ & 22 & 5.91 & 4216 & 976 & 460 & 26 & 209 & 12.4 & 8122 & 194 & $<20$ & $<0.01$ & 3.8 & 0.56 & 0.09 & $<0.15$ & 0.66 & 22715 \\
\hline $\begin{array}{l}\text { Feature-11 } \\
\text { RONGO } 1\end{array}$ & 2013000040 & $05 / 11 / 2012$ & 22 & 6.99 & 9.7 & 5.3 & 4 & 1.2 & 169 & $<0.3$ & 2.3 & 4.2 & 47 & $<0.01$ & 0.009 & $<0.015$ & $<0.02$ & $<0.15$ & $<0.005$ & 139 \\
\hline $\begin{array}{l}\text { Feature-14 } \\
\text { MATAGELE }\end{array}$ & 2013000041 & $06 / 11 / 2012$ & 22 & 3.51 & 6.2 & 4.1 & 23 & 7.1 & 110 & $<0.3$ & 0.4 & 117 & $<20$ & 0.02 & 0.32 & $<0.015$ & 0.48 & 0.63 & 0.79 & 395 \\
\hline $\begin{array}{l}\text { Feature-15 } \\
\text { MAGILAE }\end{array}$ & 2013000042 & $06 / 11 / 2012$ & 22 & 3.64 & 9.1 & 2.5 & 5.8 & 2.3 & 77 & $<0.3$ & 2.4 & 117 & $<20$ & 9.6 & 0.03 & $<0.015$ & 5.2 & 1.1 & 0.19 & 242 \\
\hline $\begin{array}{l}\text { Feature- } \\
17 \text { LAKE } \\
\text { DAKATAUA }\end{array}$ & 2013000043 & $07 / 11 / 2012$ & 22 & 7.33 & 41 & 3.1 & 11.7 & 6.8 & 31 & $<0.3$ & 24 & 30 & 68 & 0.02 & 0.03 & $<0.015$ & 0.02 & $<0.15$ & $<0.005$ & 284 \\
\hline $\begin{array}{l}\text { Feature-18 } \\
\text { WUDI }\end{array}$ & 2013000044 & $08 / 11 / 2012$ & 22 & 2.01 & 6.1 & 8.3 & 4.1 & 1.2 & 344 & 0.47 & 1.9 & 1075 & 29 & 14.4 & 5.2 & 0.015 & 20 & 43 & 0.22 & 4783 \\
\hline $\begin{array}{l}\text { Feature-23 } \\
\text { GALU }\end{array}$ & 2013000045 & $10 / 11 / 2012$ & 22 & 1.93 & 29 & 10.5 & 58 & 25 & 256 & 2 & 415 & 790 & 21 & 24.3 & 0.39 & 0.07 & 8.8 & 56 & 1.2 & 6109 \\
\hline $\begin{array}{l}\text { Feature-24 } \\
\text { TABERO }\end{array}$ & 2013000046 & $10 / 11 / 2012$ & 22 & 1.82 & 39 & 13 & 75 & 33 & 334 & 3.2 & 595 & 1025 & $<20$ & 0.4 & 0.51 & 0.09 & 15 & 76 & 1.7 & 8035 \\
\hline $\begin{array}{l}\text { Feature-28 } \\
\text { BAKAMA } \\
1\end{array}$ & 2013000047 & $11 / 11 / 2012$ & 22 & 6.19 & 1710 & 193 & 200 & 2 & 131 & 24 & 12888 & 28 & 27 & $<0.01$ & 0.46 & 0.84 & $<0.08$ & $<0.15$ & 0.1 & 33725 \\
\hline $\begin{array}{l}\text { Feature-29 } \\
\text { TALIAU }\end{array}$ & 2013000048 & $11 / 11 / 2012$ & 22 & 3.2 & 11.4 & 1.8 & 25 & 7.8 & 128 & 1.6 & 1.1 & 235 & $<20$ & 0.04 & 11.1 & $<0.015$ & 11.8 & 7.8 & 0.31 & 856 \\
\hline $\begin{array}{l}\text { Feature-30 } \\
\text { SAKALU }\end{array}$ & 2013000049 & $11 / 11 / 2012$ & 22 & 7.43 & 5968 & 1177 & 462 & 0.45 & 205 & 105 & 11357 & 32 & $<20$ & $<0.01$ & 0.46 & 7.2 & $<0.08$ & $<0.15$ & 0.19 & 30260 \\
\hline $\begin{array}{l}\text { Feature-32 } \\
\text { MAGOURU }\end{array}$ & 2013000050 & $12 / 11 / 2012$ & 21 & 7.2 & 6626 & 1401 & 496 & 3.9 & 420 & 92 & 3097 & 101 & 34 & 0.06 & 16.7 & 9.5 & $<0.08$ & $<0.15$ & 4 & 9335 \\
\hline Seawater & & & & 8 & 10450 & 354 & 405 & 1235 & 0.428 & 4.1 & 19520 & 2748 & 154 & & & $3.7^{*}$ & $15^{*}$ & & $16^{*}$ & \\
\hline
\end{tabular}

$*$ in $\mu \mathrm{g} \mathrm{L}-1$

Table 3. Water (solute) geothermometers (temperatures in C) generated using a spreadsheet created by Powell and Cumming (2010), based on Giggenbach (1991). Immature waters are omitted.

\begin{tabular}{llllllllll}
\hline $\begin{array}{l}\text { Sample } \\
\text { name }\end{array}$ & $\begin{array}{l}\text { Meas. } \mathrm{T} \\
{ }^{\circ} \mathrm{C}\end{array}$ & $\begin{array}{l}\mathrm{T}_{\mathrm{AmS}} \\
\text { Cond. }\end{array}$ & $\begin{array}{l}\mathrm{T}_{\mathrm{Ch}} \\
\text { Cond. }\end{array}$ & $\begin{array}{l}\mathrm{T}_{\mathrm{QZ}} \\
\text { Cond. }\end{array}$ & $\begin{array}{l}\mathrm{T}_{\mathrm{Na}-\mathrm{K}-\mathrm{Ca}} \\
\mathrm{T}_{\mathrm{Na}-\mathrm{K}-\mathrm{Ca}} \\
\mathrm{Mg} \text { corr }\end{array}$ & $\begin{array}{l}\mathrm{T}_{\mathrm{Na} / \mathrm{K}} \\
\text { Fournier (1979)* }\end{array}$ & $\begin{array}{l}\mathrm{T}_{\mathrm{Na} / \mathrm{K}} \\
\text { Giggenbach (1988) }\end{array}$ & $\begin{array}{l}\mathrm{T}_{\mathrm{Na} / \mathrm{K}} \\
\text { Giggenbach (1986) }\end{array}$ \\
\hline Rabili & 100 & 118 & 233 & 246 & 273 & 265 & 286 & 296 & 230 \\
Talasea Station & 100 & 59 & 162 & 184 & 271 & 239 & 301 & 310 & 197 \\
Bakama 1 & 70 & 31 & 128 & 153 & 210 & 210 & 228 & 242 & 182 \\
Sakalu & 100 & 58 & 161 & 182 & 267 & 267 & 283 & 293 & 318 \\
Magouru & 100 & 112 & 226 & 240 & 275 & 275 & 291 & 300 & 262 \\
\hline
\end{tabular}

* These references can be found within the work of Powell and Cumming (2010).

history of a fluid in its path from the reservoir to the surface (Giggenbach, 1988). The most widely used liquid geothermometers involve silica concentration and relative concentrations of the cations $\mathrm{Na}, \mathrm{K}, \mathrm{Mg}$ and $\mathrm{Ca}$. Hence, geothermometry calculations were applied to Sakalu, Magouru, Rabili, Talasea Station and Bakama 1 chemical analyses, which generated the calculated geothermometry temperatures in Table 3 .

Amorphous silica temperatures for Talasea Station, Bakama 1 and Sakalu are lower than the measured values (Table 3) while higher for Rabili and Magouru. This low silica geothermometry is a possible indication of dilution with cold water before reaching the surface or precipita- tion of silica before sample collection. The subsurface reservoir temperatures obtained by $\mathrm{Na}-\mathrm{K}-\mathrm{Ca}$ and $\mathrm{Na} / \mathrm{K}$ geothermometers compare well with the values obtained from the quartz and chalcedony geothermometer temperatures for Rabili and Magouru but not so for Talasea Station, Bakama 1 and Sakalu. The calculated quartz geothermometer temperatures for the Rabili, Talasea Station, Bakama 1, Sakalu and Magouru hot springs indicate reservoir temperatures of 246, $184,153,182$ and $240^{\circ} \mathrm{C}$ respectively. The $\mathrm{Na} / \mathrm{K}$ and $\mathrm{Na}-\mathrm{K}-$ $\mathrm{Ca}$ geothermometers indicate reservoir temperatures of 270 295, 270-310, 210-240, 265-290 and $275-300^{\circ} \mathrm{C}$ for Rabili, Talasea Station, Bakama 1, Sakalu and Magouru hot springs respectively. 


\section{Conclusions}

West New Britain Province is ideally located within an active tectonic region and is a favourable environment for geothermal activity. The occurrence of geothermal surface features is confined to the Quaternary Kimbe Volcanics, which are comprised mainly of basaltic to rhyolitic pyroclastics and lavas and in recent alluvium areas in the lowlands. The geothermal activities in the Willaumez Peninsula appear to be controlled by deep-seated northerly trending faults while those in Hoskins are unknown.

The geochemical analysis of water samples from the area reveals four prospective geothermal prospects:

1. Pangalu (Rabili) $-270-295^{\circ} \mathrm{C}$

2. Talasea Station $-270-310^{\circ} \mathrm{C}$

3. Silanga (Bakama and Sakalu) $-210-290^{\circ} \mathrm{C}$

4. Kasiloli (Magouru) $-275-300^{\circ} \mathrm{C}$.

The Pangalu and Talasea Station geothermal prospects are located near the shoreline and are likely to be influenced by seawater. Isotopic analysis is required in determining the source of the geothermal waters in these prospects as well as determining the likely contamination of seawater. It is noted that there is lack of gas and isotopic data analysis on the prospects investigated. It is therefore recommended that isotopic analysis is performed including the use of proper equipment in collecting gas samples to further analyse and correlate these data with the available geochemistry data.

Further investigations are required in surface geology mapping, geophysics surveys and geochemical surveys of hot springs not sampled yet to delineate the prospectivity of these geothermal prospects for development of geothermal energy.

Acknowledgements. The authors wish to thank the PNG Mineral Resources Authority and the World Bank through its Technical Assistance (WBTA2) program for funding this investigation. We thank Lynn Orari and Dorothy Pion of Geological Survey Division, Mineral Resources Authority, for their assistance in reproducing the geology map of the study area. Our sincere thanks and gratitude go to the West New Britain Provincial authorities and the local people for their support and assistance during the field work.

Edited by: H. Rüter

Reviewed by: L. Georgsson and one anonymous referee

\section{References}

Berhane, D. and Mosusu, N.: A review of the geothermal resources in Papua New Guinea, Proceedings, PNG Geology, Exploration and Mining Conference, Madang, Papua New Guinea, 15-27, 1997.

Cooper, P. and Taylor, B.: Seismicity and focal mechanisms at the New Britain Trench related to deformation of the lithosphere, Technophysics, 164, 25-40, 1989.
Davies, H. L.: New Guinea Geology, Encyclopedia of islands edited by RG Gilespie and DA Clague, University of California Press, Berkeley, CA, USA, 659-665, 2009.

Giggenbach, W. F.: Geothermal solute equilibria, Derivation of NaK-Mg-Ca geoindicators, Geochim. Cosmochim. Ac., 52, 27492765, 1988.

Giggenbach, W. F.: Chemical techniques in geothermal exploration in Application of geochemistry in geothermal reservoir development, UNITAR/UNDP publication, Rome, Italy, 119-142, 1991.

Grindley, G. W. and Nairn, I. A.: Geothermal investigations in Papua New Guinea, New Zealand Geological Survey Unpublished Report M9, Department of Scientific and Industrial Research, New Zealand, 30 pp., 1974.

Johnson, T. and Molnar, P.: Focal mechanisms and plate tectonics of the Southwest Pacific, J. Geophys. Res., 77, 5000-5032, 1972.

Lowder, G. G. and Carmichael, I. S. E.: The volcanoes and caldera of Talasea, New Britain: geology and petrology, Geol. Soc. Am. Bull., 81, 17-38, 1970.

McCoy-West, A. J., Bignall, G., and Harvey, C. C.: Geothermal power potential of selected Pacific Nations, GNS Science Consultancy Report 2009/180, GNS Science, New Zealand, 95 pp. 2009.

NRI Report 2010: Papua New Guinea District and Provincial Profiles, The National Research Institute, 182 pp., March 2010, 2010.

Pichler, T.: Stable and radiogenic isotopes as tracers for the origin, mixing and subsurface history of fluids in shallow-water hydrothermal systems, J. Volcanol. Geoth. Res., 193, 211-226, 2005.

Powell, T. and Cumming, W.: Spreadsheets for geothermal water and gas geochemistry, Proceedings, Thirty-Fifth Workshop on Geothermal Reservoir Engineering, Standford University, Standford, California, USA, SGP-TR-188, 10 pp., 2010.

Ripper, I. D. and McCue, J. F.: The seismic zone of the Papuan Fold Belt: BMR, Journal of Australian Geology and Geophysics, 8, 147-156, 1983.

Ryburn, R. J.: Talasea-Gasmata, New Britain - 1:250000 Geological Series, Bureau of Mineral Resources, Geology and Geophysics, Explanatory Notes, SB/56-5 and BS/56-9, 26 pp., 1975.

Sheppard, S. and Cranfield, L. C.: Geological framework and mineralization of Papua New Guinea, Mineral Resources Authority, Independent State of Papua New Guinea, 65 pp., 2012.

Williamson, A. and Hancock, G.: The geology and mineral potential of Papua New Guinea, Papua New Guinea department of Mining, 152 pp., 2005. 